\title{
Aikuiskasvatuksessa ja -koulutuksessa kaikki hyvin?
}

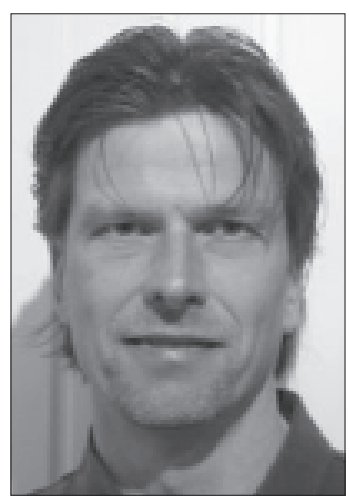

S tukseen. Aikuisten sivistystä ja koulutusta sekä näihin liittyvää tutkimusta edistämään perustetut järjestöt, organisaatiot ja instituutiot ovat yhä edelleen voimissaan. Yksi aikuiskasvatustutkimuksen lipunkantajista, Aikuiskasvatuksen Tutkimusseura, täyttää ensi vuonna 75 vuotta. Juhlavuosi käynnistyy Aikuiskasvatuksen tutkijatapaamisella Itä-Suomen yliopiston Joensuun kampuksella helmikuun puolivälissä ja päättyy arvokkain juhlallisuuksin joulukuun seitsemäntenä päivänä Helsingissä. Emeritus professorin ikään ehtinyt seura, toinen Aikuiskasvatus-lehden taustavoimista, on yhä edelleen voimissaan mukana kuvioissa.

$\mathrm{M}$ utta - juuri nyt mennyt vaikuttaa sanan varsinaisessa merkityksessä menneeltä. Aikuiskasvatuksen ja siihen liittyvän tutkimuksen rakenteiden uudistaminen näyttää olevan vasta alussa. Haastavaa tilanteessa on se, että ideologinen uudistusretoriikka näyttää irtautuneen lopullisesti empiirisestä, luotettavin mittauksin todennettavasta todellisuudesta. Tuottavuudella, tehokkuudella ja laadulla tai niitä osoittamaan laadituilla mittareilla ei enää voi perustella oman toimintansa olemassaoloa tai tarpeellisuutta. Erilaisten mittareiden ja arviointivälineiden kehittelijöille näytetään juuri nyt harvinaisen pitkää nenää. Väitän, että Suomessa on vuosien varrella saatu vaatimattomin panoksin paljon aikaan. Kentillä on palkkatyön ohella tehty paljon sivistyksellistä talkootyötä. Nyt se ei vain taida enää riittää.

Aikuiskoulutusjärjestelmän laajentuminen ja muodolliseen aikuiskoulutukseen osallistuminen on saavuttanut lakipisteensä. Järjestelmästä vaikuttaisi vuosien varrella muotoutuneen laaja-alainen mutta harvinaisen monimutkainen ja läpinäkymätön. Miksi näin päässyt käymään? Ja onko ohjausjärjestelmien valtakunnallinen kehittäminen kollektiivisesti nautittua särkylääkettä? Osallistumisen kasvu selittyy sen kasautumisella. Vaikka Suomessa on saanut sivistää ja kouluttaa itseään hyvin pienin henkilökohtaisin panoksin (kts. Aikuiskoulutustutkimus 2006. Eurooppalainen vertailu. Tilastokeskus 2009) eivät kaikki aikuiset ole omaa parastaan ymmärtäneet. Syksyllä ilmestyneen Aikuiskoulutuksen uudet teesit -raportin kirjoittajat tarjoavat koulutuksellisen tasa-arvon edistämiseksi henkilökohtaisia koulutustilejä, hintatukea ja koulutusoikeutta sekä aikuiskoulutuksen keskittämistä sivistyskeskuksiin. Mutta juuri julkiseen hintatukeen ja koulutusoikeuteen (muttei velvollisuuteen) nykyinen järjestelmä näyttäisi perustuvan. Ja muun muassa eurooppalaisen harmonisointiin vedoten näihin tukiin ja oikeuksiin tullaan jatkossa puuttumaan. Valtion vetäytyessä 
valtiosta on aktiivisen kansalaisen huomenna kehiteltävä itseään itsekseen.

\section{S}

vistyksestä kirjoittaminen ja puhuminen on kuin lämmittäisi avosaunaa Saharassa. Vaikka historialliset faktat ja kehityskulut puhuisivat kuinka puolestaan, on niitä aika lailla turha esitellä ja niiden todistusvoimaan vedota. Ymmärrän hieman häpeillen olevani parantumaton romantikko todetessani seuraavan: ”Nyt tarvittaisiin joukkovoimaa ja opintopiirejä!" Henkilökohtaiset koulutustilit korvaisin toimintaoppimisen osuuskunnilla. Välineitä osuuskuntien ja opintopiirien organisoimiseen ovat tietoverkot pullollaan - niin ikään esimerkkejä hyvistä käytännöistä. Emeritus professori Kari Uusikylä opastaa (Kasvatus 4/ 2009) meitä nuorempia kollegojaan vaikuttamaan rohkeasti omalla asiantuntemuksellamme, ottamaan kantaa ihmiseksi ja ihmisenä kasvamisen tärkeyteen, viemään etiikan teoriasta arjen käytäntöihin sekä välittämään aidosti työtoveriemme hyvinvoinnista. Joukkovoimaan edelleen vedoten totean, että tässä on meille aikuskasvattajille kollektiivisen mission aineksia. Toisaalla tässä lehdessä löytyy toukokuussa pitämäni virkaanastujaisesitelmä . Se julkaistaan poikkeuksellisesti ruotsiksi, eli kielellä jonka opin lapsena hiekkalaatikon reunalla ruotsinkielisiltä kavereiltani ja joka on virkakieleni yliopistossani Åbo Akademissa. Esitelmän toisessa lauseessa totean seuraavan;"Aikuiskasvattajan tehtävä on kautta aikain ollut sekä sivistyksellinen että poliittinen."

lmen vuoden pesti Aikuiskasvatus-lehden päätoimittajana on päättymässä. Kokemukset tiedelehden päätoimittamisesta ovat olleet pääosin myönteiset, osin kaksijakoiset. Otin toimeen tarttuessani tavoitteekseni kiireen ja keskeneräisyyden selättämisen. Olen edelleenkin yllättynyt lehteen lähetettyjen puolivalmiiden ja keskeneräisten käsikirjoitusten määrästä. Sekä toimituskunnan jäsenten että refereiden myötämielisyys ja talkoohenki ovat mahdollistanut sen, että lehti on toiminut kirjoittajakouluna. Tämä tehtävä kuuluu - nyt ja jatkossa - yliopistoille. Tieteellisen artikkelin kirjoittamisessa ja työstämisessä on pääosin hyvä pitäytyä perinteisissä malleissa. Näin toimitaan muuallakin, eli arvostetuissa kansainvälisissä alan julkaisuissa.

A ikuiskasvatusta tieteenalana on kuvattu risteysasemana ja monitasoristeyksenä. Empiiristä evidenssiäkin näille metaforille löytyy. Elektra-palvelussa (www.lib.helsinki.fi/elektra) sähköisesti saatavilla olevia lehden artikkeleita on vuosina 2006-2008 hyödynnetty (eli ladattu) tiedelehdistä selvästi eniten. Oletan, että lehden artikkeleita ovat lukeneet ja hyödyntäneet muutkin kuin aikuiskasvattajat. Latauksista saatavat tekijänoikeuskorvaukset mahdollistavat toivottavasti jatkossakin perinteisen paperilehden julkaisemisen.

Tein ensimmäisessä pääkirjoituksessani kolme vuotta sitten radikaalin uudistuksen. Pistin nimeni alle sähköpostiosoitteeni. Sähköpostia ei kolmen vuoden aikana ole tullut. Kansakunnassa kaikki hyvin?

\section{Petri Salo}

psalo@abo.fi 